\title{
PROFESSOR HERBERT PATRICK REGINALD FINBERG, M.A., D.LITT.
}

\author{
Elected r2th Fanuary 1956
}

Professor Finberg died on 1st November 1974 at the age of 74. He was Emeritus Professor of English Local History at Leicester University, and general editor of the Agrarian History of England and Wales.

He began his career in the design and production of books, working first for Basil Blackwell, then for Bernard Newdigate at the Shakespeare Head Press, before setting up his own Press, the Alcuin. He was subsequently a director of the Broadwater Press, and editorial director of Burnes Oates and Washbourne. During this period he supervised the printing of a series of liturgical works, and advised H.M. printers and the Ministry of Works.

However, it was at the age of 52 that Professor Finberg began his second career, as an academic historian, as a result of his interest in local history. He published Tavistock Abbey and was joint author, with W. G. Hoskins, of Devonshire Studies, an important collection of essays. He became lecturer in Economic History at Leicester and in 1952 succeeded Hoskins as Reader and Head of the Department of English Local History. By the time that he retired in 1965, he had published six books of his own, and launched and edited Occasional Papers in Local History, the Agricultural History Review, and the Agrarian History of England and Wales. Professor Finberg was President of the British Agricultural History Society from 1966 to 1968, and a Fellow of Clare Hall, Cambridge, from 1968 to 1969 . He was a part-time research assistant at the University of Leeds, where he worked with Maurice Beresford on their handlist of medieval boroughs. He was also a member of a committee of specialist advisers to the Vatican Council on vernacular liturgies. In 1965 he was awarded the Belgian Prix Graphica for his Manual of Catholic Prayer.

\section{SAMUEL JAMES GARTON, ESQ., O.B.E. Elected 6th March 1947}

Samuel Garton died on the 17 th February 1974. After practising privately as an architect, he entered the architectural department of the Ministry of Works, where he specialized in ancient monuments, and in 1946 he was appointed Chief Investigator of Historic Buildings-a post created following the Act of 1944, which imposed upon the Ministry of Town and Country Planning the duty of listing buildings of special architectural or historic interest. On his retirement, Samuel Garton was appointed to the Historic Buildings Council, and later to the Historic Buildings Committee of the London County Council.

\section{PROFESSOR MICHAEL RICHARD GOUGH, O.B.E., M.A.}

\section{Elected 6th May 1954}

Professor Gough died in Toronto on 25th October 1973. As an archaeologist he will be remembered particularly for his patient recording of early Christian monuments in Turkey, and his association for nearly 25 years with the British Institute of Archaeology at Ankara, of which he was one of the first students and afterwards Director.

Professor Gough was born at Newcastle upon Tyne in 1916 and educated at Peterhouse, Cambridge, where he became a Prizeman in Classical Studies. In I 947 he received a postgraduate diploma in Classical Archaeology, and was encouraged by A. W. Lawrence to study the classical antiquities of Turkey. He joined the Ankara Institute and spent two years recording the Roman city of Anazarbus. In 195 I he was appointed lecturer in Classical Archaeology at the University of Edinburgh, and this was followed by the Directorship of the Ankara Institute in 1961, and 